\title{
Characterization of the Enzymatic Defect in Late-Onset Muscle Phosphofructokinase Deficiency New Subtype of Glycogen Storage Disease Type VII
}

Shobhana Vora, ${ }^{\dagger}$ Salvatore DiMauro, David Spear, David Harker, and Moris J. Danon

Department of Basic and Clinical Research, Divisions of Biochemistry and Hematology, Scripps Clinic and Research Foundation, La Jolla, California 92037; Department of Neurology, College of Physicians and Surgeons of Columbia University, New York, New York 10032; and Department of Neurology and Pathology, University of Illinois Medical Center, Chicago, Illinois 60612

\begin{abstract}
Human phosphofructokinase (PFK) exists in tetrameric isozymic forms, at least in vitro. Muscle and liver contain homotetramers $M_{4}$ and $L_{4}$, respectively, whereas red cells contain five isozymes composed of $M$ (muscle) and $L$ (liver) type subunits, i.e., $M_{4}, M_{3} L, M_{2} L_{2}$, and $M_{3}$, and $L_{4}$. Homozygous deficiency of muscle PFK results in the classic glycogen storage disease type VII characterized by exertional myopathy and hemolytic syndrome beginning in early childhood. The genetic lesion results in a total and partial loss of muscle and red cell PFK, respectively. Characteristically, the residual red cell PFK from the patients consists of isolated $L_{4}$ isozyme; the M-containing hybrid isozymes are completely absent. In this study, we investigated an 80 -yr-old man who presented with a 10-yr history of progressive weakness of the lower limbs as the only symptom. The residual red cell PFK showed the presence of a few M-containing isozymes in addition to the predominant $\mathrm{L}_{4}$ species, indicating that the genetic lesion is a "leaky" mutation of the gene coding for the $M$ subunit. The presence of a small amount of enzyme activity in the muscle may account for the atypical myopathy in this patient.
\end{abstract}

\section{Introduction}

Phosphofructokinase (PFK; ${ }^{2}$ ATP:D-fructose-6-phosphate,1phosphotransferase [EC 2.7.1.11]), the key regulatory enzyme of glycolysis, is a tetrameric ${ }^{3}$ protein with a subunit $M_{\mathrm{r}}$ of

This paper was presented in part at the 42nd Annual Meeting of the American Federation for Clinical Research, Washington, DC, 5 May 1985.

Address reprint requests to Dr. Vora, Department of Basic and Clinical Research, Scripps Clinic and Research Foundation, 10666 North Torrey Pines Road, La Jolla, CA 92037.

Received for publication 29 October 1986 and in revised form 10 June 1987.

1. ${ }^{\dagger}$ Deceased.

2. Abbreviations used in this paper: $\mathrm{L}$, liver; $\mathrm{M}$, muscle; $\mathrm{P}$, platelet; PFK, phosphofructokinase.

3. Although the smallest active oligomer of PFK is a tetramer and, under the conditions of ion-exchange chromatography used by us, various isozymes indeed exist as tetramers in vitro, the enzyme most likely exists in a series of oligomeric species in vivo, due to its great propensity for self-aggregation. Thus, the definition of the term tetramer as used in this article is a strictly operational one and is used for the ease of description of the experimental results.

J. Clin. Invest.

(C) The American Society for Clinical Investigation, Inc.

$0021-9738 / 87 / 11 / 1479 / 07 \quad \$ 2.00$

Volume 80, November 1987, 1479-1485 $\sim 85,000$. We have previously shown that human PFK is under the control of three structural loci that code for three unique subunits, muscle (M), liver (L), and platelet (P) types $(1,2)$. A tissue may express one, two, or all three subunits, which randomly tetramerize to form various isozymes. For instance, human muscle and liver (major species) express homotetramers, $\mathrm{M}_{\mathbf{4}}$ and $\mathrm{L}_{4}$, respectively, whereas red cells contain five isozymes composed of $M$ and $L$ subunits, $M_{4}, M_{3} L$, $\mathrm{M}_{2} \mathrm{~L}_{2}, \mathrm{ML}_{3}$, and $\mathrm{L}_{4}$. In contrast, platelet PFK consists of three species composed of $P$ and $L$ subunits, i.e., $P_{4}, P_{3} L, P_{2} L_{2}$. These isozymes are distinguishable from one another by ionexchange chromatography and subunit-specific monoclonal antibodies (1-3).

Inherited deficiency of muscle PFK is known to occur in man and the dog (4-6). In man, the enzyme deficiency is associated with a heterogeneous group of clinical syndromes characterized by myopathy and/or hemolysis or asymptomatic state $(4,5)$. The most common syndrome, glycogen storage disease type VII, is characterized by the coexistence of muscle disease and hemolytic process. Typically, the muscle disease begins in early childhood and consists of easy fatigability, transient weakness and muscle cramps, and myoglobinuria after vigorous exercise. The genetic lesion(s) in most cases is shown to result in a total lack of the catalytically active muscle-type subunit(s) of PFK (5). Only one of 20 reported cases presented with a muscle disease of late-onset fixed weakness that was progressive in nature and unassociated with muscle cramps and myoglobinuria (7). The nature of the enzymatic defect was not investigated in detail.

Recently, we had an opportunity to investigate a patient with late-onset, progressive weakness restricted to the lower limbs (8). Our studies suggest that the genetic lesion in this patient is distinct from the one causing the classic disease in that the patient exhibits enzymatically active muscle-type subunits, but in a reduced amount. The late-onset muscle disease in the patient may be ascribed to both the residual muscle PFK activity and altered gene expression in the aged. Since lateonset myopathy is now well-documented in three unrelated individuals with muscle PFK deficiency (7, 8, DiMauro, S., 1985 , unpublished results), it is proposed that it be classified as a new subtype of glycogenosis type VII and be considered in the differential diagnosis of late-onset myopathies of unexplained etiology.

Case report. J.K., a retired bus driver, is an 80-yr-old Jewish man who presented in the spring of 1984 with the chief complaint of progressive weakness of both lower limbs for the last $10 \mathrm{yr}$. On examination, the weakness was found to be rather fixed in and around the quadriceps muscles of both legs; there was no weakness of shoulder girdle or arm muscles. His shoulder girdle was found to be rather powerful, in sharp con- 
trast to his legs, which appeared dystrophic. Although he gave a history of easy fatigability and inability to keep up with others, he had never suffered from muscle cramps and myoglobinuria after exertion. In particular, during gymnasium classes at school, group play activities and running up two to three flights of stairs, he felt increasing weakness, nausea, and vomiting, but never muscle spasms and myoglobinuria. Nausea and vomiting with or without intense gastric pain and backache are the prodromal features of myoglobinuria and acute renal obstruction associated with intense exercise in PFK-deficient patients. One of his now deceased sisters apparently had similar problems. She also began experiencing chronic, progressive weakness of both extremities at age 74 , and died of complications associated with a pelvic fracture at age 84. Clinical details of the case will be described elsewhere (Danon, M. J., S. DiMauro, N. Bresolin, S. Shanske, and S. Vora. Submitted for publication).

The blood specimens from the patient were studied intermittently over the last $3 \mathrm{yr}$. The bulk of the studies were done in the summer of 1984, throughout 1985, and spring of 1986 and 1987.

During the fall of 1985 and spring of 1986 , five additional patients were referred to us from four unrelated families with the possible diagnosis of muscle PFK deficiency. All of them were indeed found to suffer from muscle PFK deficiency of the classic type, and two of four served as the concurrent controls for the column chromatographic and immunoprecipitation studies of J.K.'s red cell PFK.

\section{Methods}

Chemicals and reagents. Adenine nucleotides, NADH, fructose 6phosphate, fructose 1,6-diphosphate, dithiothreitol, $\alpha$-cellulose, and microcrystalline cellulose were purchased from Sigma Chemical Co., St. Louis, MO. Fructose diphosphate aldolase, $\alpha$-glycerol 3-phosphate dehydrogenase, and triose phosphate isomerase were from Boehringer Mannheim Biochemicals, Indianapolis, IN. DEAE-Sephadex A-25, Sepharose 4B, and Sephadex G-200 were from Pharmacia Fine Chemicals, Piscataway, NJ, whereas Ultrogel AcA 22 was a product of LKB Instruments, Inc., Gaithersburg, MD. Ultrogel ACA 22 has a linear fractionation range of $1 \times 10^{5}-1.2 \times 10^{6}$ for globular proteins and an exclusion limit of $3 \times 10^{6}$. Molecular markers for gel filtration were purchased from Pharmacia Inc. Nonidet P-40 was purchased from Particle Data, Inc., Elmhurst, IL, and staphylococci bearing protein A (IgGSorb) were from The Enzyme Center, Boston, MA. All other chemicals were of reagent grade.

Assays of PFK activity. Assays were performed with a model 260 spectrophotometer (Gilford Instrument Laboratories, Inc., Oberlin, $\mathrm{OH})$ at $26^{\circ} \mathrm{C}$ as described previously (1). The assay mixture was preincubated for $10 \mathrm{~min}$ before the addition of the enzyme. The auxiliary enzymes were free of contaminating PFK activity and the blanks (without the added PFK or substrate) were zero. $1 \mathrm{U}$ of enzyme is defined as that amount of enzyme that converts $1 \mu \mathrm{mol}$ of Fru-6-P to Fru-1,6- $\mathrm{P}_{\mathbf{2}}$ in $1 \mathrm{~min}$ in the above system.

Preparation of pure cell suspensions. Fresh venous blood samples (heparinized and defibrinated) were obtained simultaneously from the PFK-deficient patient and his daughter as well as healthy volunteers serving as controls. Pure red cell suspensions were obtained by filtration of whole blood on $\alpha$-cellulose and microcrystalline cellulose columns according to the method of Beutler (9). Hemolysates were prepared just before chromatography and immunoprecipitation studies by the addition of an equal volume of $10 \mathrm{mM}$ potassium phosphate buffer (pH 8.0) containing $0.2 \mathrm{mM}$ EDTA, $0.2 \mathrm{mM}$ AMP, $0.7 \mathrm{mM}$ dithiothreitol, and $0.2 \%$ saponin to the packed red cells.
Chromatographic separation of PFK isozymes. PFK isozymes were resolved by using DEAE-Sephadex A-25 ion-exchange chromatography at $4^{\circ} \mathrm{C}$ as described previously $(1,10)$. Briefly, a $1.6 \times 30-\mathrm{cm}$ column was equilibrated in $0.1 \mathrm{M}$ Tris-phosphate buffer ( $\mathrm{pH} \mathrm{8.0)}$, containing $25 \mathrm{mM} \mathrm{NaCl}, 0.2 \mathrm{mM}$ EDTA, $0.2 \mathrm{mM} \mathrm{AMP}$, and $0.7 \mathrm{mM}$ dithiothreitol. The column was loaded with hemolysates containing $0.1-0.12 \mathrm{U}(\sim 1 \mu \mathrm{g}$ PFK considering a specific activity of $100 \mathrm{U} / \mathrm{mg})$. A $300-\mathrm{ml}$ concave elution gradient of $\mathrm{NaCl}$ was prepared by using three chambers of a Varigrad nine-chambered gradient mixer, as described previously (10). A total of $100 \times 3 \mathrm{ml}$ fractions were collected and assayed for PFK activity. By this technique, the three homotetramers are clearly distinguished from one another by their relative positions of elution. $M_{4}$ tetramer is eluted first at $214 \mathrm{mosmol} / \mathrm{kg}$ ( 40th fraction), and $\mathrm{L}_{4}$ tetramer is eluted last at $480 \mathrm{mosmol} / \mathrm{kg}$ ( $\sim 75$ th fraction), whereas $P_{4}$ tetramer is eluted very close to $M_{4}$ tetramer, at $244 \mathrm{mosmol} / \mathrm{kg}(\sim 47$ th fractions) $(1,2,10)$. It is noteworthy that the resolution of various isozymes is not feasible if $>0.15-0.2 \mathrm{U}$ ( $\sim 2 \mu \mathrm{g}$ PFK) is chromatographed.

Gel filtration chromatography. To assess the aggregation state and hence molecular weight of the PFK isozymes resolved by ion-exchange chromatography, gel filtration studies were undertaken employing the frontal elution technique described by Winzor (11) and applied to mammalian PFK by various investigators (12-15). Pilot experiments were undertaken to investigate various gel filtration matrices (Sepharose 4B, Sephadex G-200, and Ultrogel AcA 22) for their suitability for frontal elution chromatography of PFK using several different column sizes $(1 \times 30,1.5 \times 30,2.6 \times 30 \mathrm{~cm})$. Because of the high separation efficiency and high mechanical strength, Ultrogel AcA 22 was chosen for frontal elution procedure. Experiments were performed at $4^{\circ} \mathrm{C}$ with a $1.5 \times 30 \mathrm{~cm}$ Ultrogel AcA 22 column equilibrated with the very same buffer used for ion-exchange chromatography. The column was packed and eluted exactly according to the manufacturer's instructions. Before the frontal elution studies, hemoglobin was removed from freshly prepared hemolysates using a $1.0 \times 10$-cm DEAE-Sephadex A-25 ion exchange column equilibrated with the standard column buffer. The column was loaded with $3 \mathrm{ml}$ of hemolysate containing 1.7 $\mathrm{U} / \mathrm{ml}$ PFK. The hemoglobin was eluted in $25 \mathrm{ml}$ of column buffer. No PFK was present in the hemoglobin effluent. To elute the PFK, the column was rinsed with $10 \mathrm{ml}$ of standard column buffer containing $0.3 \mathrm{M} \mathrm{NaCl}$. A total of $5 \times 2-\mathrm{ml}$ fractions were collected and assayed for PFK activity. The peak was observed in fraction number 3 at 264 mosmol/ $\mathrm{kg} \mathrm{H}_{2} \mathrm{O}$. The peak PFK fraction was diluted in the column buffer to yield a concentration of $0.008 \mathrm{U} / \mathrm{ml}$. The diluted enzyme solution was then continuously applied to the column until the catalytic activity in the effluent was the same as that of the applied sample. The bed volume was constant during all the experiments and constant volume fractions of $1.0 \mathrm{ml}$ were collected with the aid of an Ultrorac 2000 (LKB Instruments, Inc.); flow rate was $10 \mathrm{ml} / \mathrm{h}$. To determine the relative $M_{\mathrm{r}}$ of PFK at a concentraton of $0.008 \mathrm{U} / \mathrm{ml}$, ferritin $\left(M_{\mathrm{r}}\right.$ $=440,000)$ and aldolase $\left(M_{\mathrm{r}}=158,000\right)$ were used as molecular weight markers.

Enzyme immunoprecipitation assays. The presence of M-containing isozymes in the patient's red cells was confirmed by active enzyme immunoprecipitation assay utilizing the monoclonal anti-M antibody as described previously (3). The anti-M and anti-L antibodies show strict subunit specificity and when used in excess precipitate not only the respective homotetramer but also heterotetramers containing one or more of the homologous subunit(s). For instance, anti-M antibody completely precipitates not only $M_{4}$ but also the $M_{3} L$ and $M_{2} L_{2}$ heterotetramers (3). The precipitated enzyme activities were expressed as percentages of the concurrent controls; only the precipitation values $>7 \%$ were considered significant (16). Each hemolysate was tested in duplicate with duplicate controls on several separate occasions. Both normal individuals and classic disease patients served as concurrent controls to confirm the presence of the $M$ subunits in the propositus' hemolysates. The hybrid species and $L_{4}$ isozyme from the patient's red cells were resolved into two separate pools by linear gradient elution as described previously (1) and subjected to immunoprecipitation stud- 
ies. Similarly the selected peak fractions of the hybrid isozymes and $\mathrm{L}_{4}$ isozyme were also tested.

Red cell 2,3-DPG and ATP assays. Fresh whole blood was added immediately from the syringe to an equal volume of ice-cold $2 \mathrm{~N}$ perchloric acid, and the neutralized supernatant was stored at $-20^{\circ} \mathrm{C}$. The levels of ATP and 2,3-DPG were measured by spectrophotometry within the next 4-6 d, as described by Beutler (17).

In vivo stability of residual red cell PFK. In vivo stability of the residual red cell PFK from the patient was assessed by determining the ratio of enzyme activities of the lightest and densest red cell subpopulations separated by using the technique of density-gradient centrifugation. The pure red cell suspensions from the propositus and control individuals were fractionated into populations of increasing mean cell density and presumably age according to the technique described by Vettore et al. (18).

\section{Results}

Hematological and biochemical studies. Table I compares the results of the present studies with those of classic disease patients (5) and a single case of late-onset muscle disease (7) reported in the literature. The propositus showed mild anemia with low normal hemoglobin level and moderate reticulocytosis. His daughter also showed mild anemia but a normal reticulocyte count. PFK activity was 51 and $63 \%$ of normal in the red cells from the propositus and his daughter, respectively. Muscle glycogen was mildly elevated in the propositus, whereas red cell 2,3-DPG levels were $\sim 50$ and $\sim 74 \%$ in the father and daughter, respectively. Although the propositus showed normal serum uric acid levels, he has suffered from gout since his early twenties; the latter has been well controlled by allopurinal over the years.

Chromatographic studies of red cell PFK. Fig. 1 A shows the representative isozymic profile of red cell PFK from normal individuals. As shown, it consists of a mixture of five isozymes composed of the $M$ and $L$ subunits $M_{4}, M_{3} L, M_{2} L_{2}$, $\mathrm{ML}_{3}$, and $\mathrm{L}_{4}$. Note that $\mathrm{M}_{4}$ elutes first, $\mathrm{L}_{4}$ last, and the three hybrid isozymes in intermediate positions. Fig. $1 B$ shows the representative red cell PFK profile of patients with typical gly- cogen storage disease type VII. Because of total lack of the M subunit, their residual red cell PFK consists exclusively of $\mathrm{L}_{4}$ type isozyme; the hybrid species of $M+L$ are completely absent. An exclusive $L_{4}$ type isozyme was also demonstrated in the two classic disease patients studied concurrently with the propositus. In contrast, the residual red cell PFK from the propositus, although consisting predominantly of the $\mathrm{L}_{4}$ isozyme, also shows a few early-eluting species that appear to be hybrids composed of $\mathrm{M}+\mathrm{L}$ subunits (Fig. $1 C$ ). His daughter's red cell PFK shows a similar chromatographic profile except for a greater proportion of the hybrid isozymes that also elute earlier as compared with those of her father's red cell PFK (Fig. $1 D)$.

Gel filtration studies. As shown in Fig. 2, PFK solution at a concentration of $0.008 \mathrm{U} / \mathrm{ml}(0.8 \mu \mathrm{g} / \mathrm{ml})$ eluted after ferritin $\left(M_{\mathrm{r}}=440,000\right)$ and before aldolase $\left(M_{\mathrm{r}}=158,000\right)$, indicating that the enzyme is a tetramer at this protein concentration. These results are in accord with those of other investigators working with both human red cell (21-23), rabbit red cell (24), and rat liver $(15,16)$ PFKs. During ion-exchange chromatography, the enzyme concentrations of the various fractions range from 0.001 to $0.015 \mathrm{U} / \mathrm{ml}$, i.e., $10 \mathrm{ng}$ to $150 \mathrm{ng} / \mathrm{ml}$. Since, at these concentrations, PFK exists as a tetramer, we conclude that the isozymic species eluting earlier than $\mathrm{L}_{4}$ isozyme are also tetramers and not polymers of the $\mathrm{L}_{4}$ isozyme.

Immunologic studies. The presence of $\mathrm{M}$ subunit-containing isozymes in the red cells from the patient and his daughter was confirmed by immunoprecipitation studies. As shown in Table II, anti-M monoclonal antibody precipitates $\sim 44$ and $\sim 56 \%$ of PFK activity from patient and his daughter as compared with $\sim 82 \%$ from normal individuals and none from patients with the typical disease. As expected, the residual red cell PFK from concurrently studied classic disease patients also showed a total lack of precipitation by anti-M antibody. In contrast, anti- $\mathrm{L}$ antibody precipitates $\sim 90 \%$ of red cell PFK from both groups of patients and normal individuals. As shown in Table III, the separated pools of pure $\mathrm{L}_{4}$ and non- $\mathrm{L}_{4}$ (hybrid) isozymes and various peak fractions thereof from

Table I. Hematological and Biochemical Values of Propositus and His Daughter Compared with Those of Other Patients and Normal Individuals

\begin{tabular}{|c|c|c|c|c|c|c|c|c|}
\hline \multirow[b]{2}{*}{ Patients } & \multicolumn{8}{|l|}{ PFK activities } \\
\hline & Hemoglobin & Hematocrit & Reticulocytes & Muscle & Red cells & $\begin{array}{l}\text { Muscle } \\
\text { glycogen }\end{array}$ & Uric acid & $\begin{array}{l}\text { Red cell } \\
\text { 2,3-DPG }\end{array}$ \\
\hline & $g / d l$ & $\%$ & $\%$ & $U / g$ protein & $U / g$ hemoglobin & $g \%$ & $m g / d l$ & $\mu \mathrm{mol} / \mathrm{g}$ hemoglobin \\
\hline \multicolumn{9}{|l|}{ Late-onset } \\
\hline Propositus & 13.4 & 43 & 4.4 & 0 & $6.34(51 \%)$ & 1.76 & 4.9 & $6.71(50 \%)$ \\
\hline Daughter & 11.8 & 36 & 0.9 & ND & $7.91(63 \%)$ & ND & ND & $10(74 \%)$ \\
\hline Hays et al. (1)* & 12.1 & 38 & 3.8 & 0.17 & 5.41 & 2.13 & ND & ND \\
\hline \multicolumn{9}{|l|}{ Early-onset } \\
\hline Vora et al. $(3)^{*}$ & $14.1-18$ & $44-54$ & $2.9-11$ & 0.35 & $6.38-8.42$ & $2-2.1$ & $7.2-13.6$ & $4.88-6.22$ \\
\hline Controls $(6)^{*}$ & $14-17$ & $42-52$ & $<1$ & 15 & $12.51 \pm 1.4$ & $\sim 1$ & $2.5-8$ & $12.3 \pm 1.9$ \\
\hline
\end{tabular}

* Data cited from references 5 and 7 for comparison. Numbers in parentheses indicate number of individuals studied. Percentages in parentheses indicate percentages of concurrent control assays. 


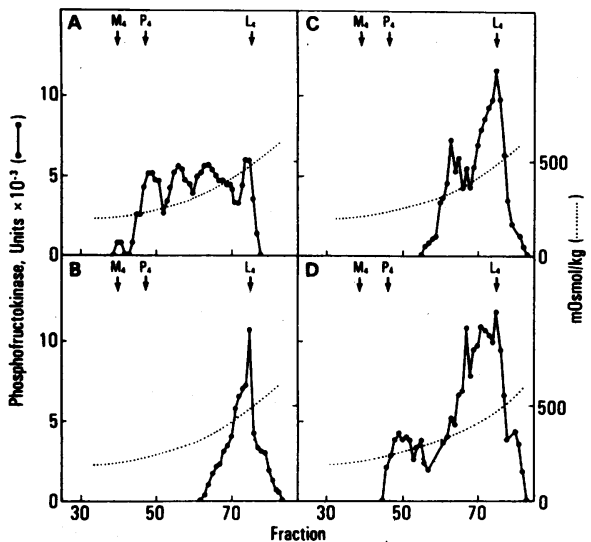

Figure 1. Representative PFK isozymic profile of red cells from normal and enzyme-deficient individuals resolved by chromatography on DEAE Sephadex A-25 column $(1.6 \times 30 \mathrm{~cm})$ equilibrated with $0.1 \mathrm{M}$ Tris- $\mathrm{P}(\mathrm{pH} 8.0)$ at $4^{\circ} \mathrm{C}$. $(A)$ Normal red cells contain a heterogeneous mixture of five isozymes; $\mathrm{M}_{4}, \mathrm{M}_{3} \mathrm{~L}, \mathrm{M}_{2} \mathrm{~L}_{2}, \mathrm{ML}_{3}$, and $\mathrm{L}_{4}$. (B) Residual red cell PFK from patients with the early-onset disease consisting of an isolated $\mathrm{L}_{4}$ isozyme. $(C)$ Red cell PFK from the patient with the late-onset disease consisting predominantly of $\mathrm{L}_{4}$ isozyme but a few hybrids of $\mathrm{M}+\mathrm{L}$ subunits are also present. $(D)$ Red cell PFK from the heterozygous daughter of the subject studied in $(C)$. Note the presence of significant amounts of the hybrid isozymes of $\mathbf{M}+\mathbf{L}$.

normal individuals and the propositi (Fig. 1) showed the expected precipitation values with the antibodies. The $\mathrm{L}_{4}$ isozyme pool and peak were precipitated almost completely ( $>90 \%$ ) by anti-L antibody but not at all by anti-M antibody. In contrast, the hybrid isozyme peaks and pool were precipitated $\sim 80-90 \%$ by both anti-M and anti- $\mathrm{L}$ antibodies.

In vivo stability of residual red cell PFK. The PFK activity ratio of the youngest ( $\sim 15 \%$ of the total) to the oldest red cells ( $\sim 15 \%$ of the total) in the propositus was comparable with that of control subjects, i.e., 1.1-1.2, indicating that the residual red cell PFK in the patient was not excessively unstable in vivo.

\section{Discussion}

Since the original reports by Tarui et al. (23) and Layzer et al. (24), 43 additional cases of PFK deficiency from 32 unrelated

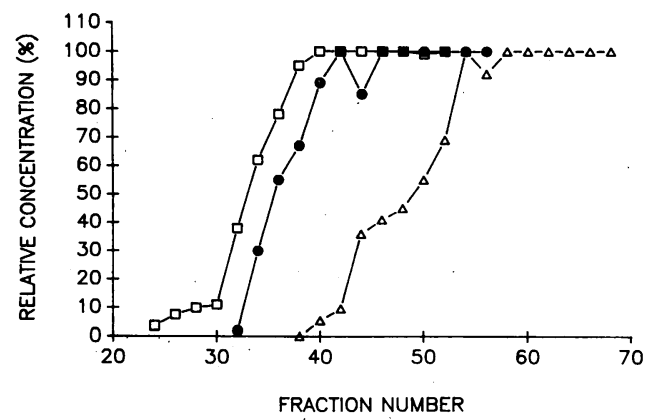

Figure 2. Representative frontal elution chromatographic profiles of red cell PFK $(\bullet)\left(M_{\mathrm{r}}=330,000\right)$, ferritin $(\square)\left(M_{\mathrm{r}}=440,000\right)$, and aldolase $(\Delta)\left(M_{\mathrm{r}}=158,000\right)$. Red cell PFK at $0.008 \mathrm{U} / \mathrm{ml}(\sim 80 \mathrm{ng} / \mathrm{ml})$.
Table II. Immunoprecipitation Values of Red Cell PFK from Propositus and His Daughter

\begin{tabular}{lll}
\hline & \multicolumn{2}{c}{ Percent precipitation* } \\
\cline { 2 - 3 } Propositi/controls & Anti-M antibody & Anti-L antibody \\
\hline Atypical & & \\
Propositus & $44+4.8$ & $92.0+2.8$ \\
Daughter & $56+5.6$ & $89.0+3.2$ \\
Typical & & \\
Vora et al. $(3)^{\ddagger}$ & $1.1+1.4$ & $92.4+1.9$ \\
Controls $(6)^{\ddagger}$ & $82+6.8$ & $88.0+4.1$ \\
\end{tabular}

* Values given are percent of enzyme activity precipitated by the respective antibody compared with those of the concurrent control assays from which antibody is omitted. Each value represents the mean of two to six determinations carried out on each individual in duplicate on separate occasions; values $<7.2 \%$ are not significant (16). ${ }^{\ddagger}$ Data cited from Vora et al. (5) for comparison.

families have been described (for details, see references 4, 5 , $25,29)$. As shown in Table IV, these cases can be divided into five major groups based on clinical and laboratory findings: Group I, patients with the "classic" disease, i.e., simultaneous presence of myopathy and hemolysis; Group II, patients with isolated myopathy; Group III, individuals with isolated hemolysis; Group IV, asymptomatic individuals who manifest partial red cell PFK deficiency; and Group V, patients with infantile, rapidly progressive, fatal myopathy associated with other atypical features. The most common syndrome, glyco-

Table III. Immunoprecipitation Values of Various Isozyme Pools and Peak Fractions

\begin{tabular}{lll}
\hline & \multicolumn{2}{l}{ Percent precipitation* } \\
\cline { 2 - 3 } & Anti-M antibody & Anti-L antibody \\
\hline Propositus & & \\
$\mathrm{L}_{4}$ pool & 0 & $90.2 \pm 3.3$ \\
$\mathrm{~L}_{4}$ peak & 0 & $89.8 \pm 5.6$ \\
Non- $\mathrm{L}_{4}$ pool & $85.3 \pm 7.5$ & $78.7 \pm 5.4$ \\
Fraction No. 63 & $75.1 \pm 5.6$ & $81.6 \pm 3.9$ \\
Fraction No. 67 & $77.8 \pm 3.2$ & $83.4 \pm 4.7$ \\
& & \\
Daughter & & $87.3 \pm 3.4$ \\
$\mathrm{~L}_{4}$ pool & 0 & $88.1 \pm 6.5$ \\
$\mathrm{~L}_{4}$ peak & 0 & $78.3 \pm 3.8$ \\
Non- $\mathrm{L}_{4}$ pool & $86.5 \pm 8.5$ & $88.3 \pm 7.5$ \\
Fraction No. 49 & $94.3 \pm 3.7$ & $95.3 \pm 3.4$ \\
Fraction No. 67 & $78.5 \pm 4.9$ & \\
\hline
\end{tabular}

\footnotetext{
* Values given are percent of enzyme activity precipitated by the respective antibody compared with those of the concurrent control assays from which antibody is omitted. Each value represents the mean of two determinations carried out on each sample; values $<7.2 \%$ are not significant (16).
} 


\begin{tabular}{|c|c|c|c|c|c|c|c|c|}
\hline \multirow[b]{2}{*}{ Classification } & \multirow[b]{2}{*}{ No. of cases/kindred } & \multirow[b]{2}{*}{$\mathbf{H b}$} & \multirow[b]{2}{*}{ Reticulocytes } & \multicolumn{2}{|c|}{ Enzyme activity } & \multicolumn{2}{|c|}{$\begin{array}{l}\text { Immunoprecipitation of } \\
\text { red cell PFK }\end{array}$} & \multirow[b]{2}{*}{ Other findings } \\
\hline & & & & Muscle & RBC & Anti-M & Anti-L & \\
\hline & & $g \%$ & $\%$ & \% of normal & & $\%$ & $\%$ & \\
\hline $\begin{array}{r}\text { Group I (myopathy } \\
\text { and hemolysis) }\end{array}$ & $28 / 22(65 \%)^{\ddagger}$ & & & & & & & \\
\hline Early-onset $^{\S}$ & $25 / 19$ & $12-18$ & $3-18$ & $0-5$ & $29-67$ & $0^{*}$ & $92 \pm 2^{*}$ & $\begin{array}{l}\text { Generalized transient } \\
\text { weakness; muscle } \\
\text { glycogenesis; } \\
\text { myoglobinuria; low 2,3- } \\
\text { DPG; hyperuricemia; only } \\
\mathrm{L}_{4} \text { in RBC. }\end{array}$ \\
\hline Late-onset & $2 / 3$ & $12-14$ & $4-5$ & $0-1$ & $43-54$ & ND & ND & Fixed and progressive \\
\hline (present report) & $1 / 3$ & 13.4 & 4.4 & 0 & 51 & $44 \pm 5$ & $92 \pm 3$ & $\begin{array}{l}\text { weakness of extremities; no } \\
\text { muscle cramps and } \\
\text { myoglobinuria; low } \\
\text { 2,3-DPG; hyperuricemia; } \\
\mathrm{L}_{4}+\text { hybrids of } \mathrm{M}+\mathrm{L} \\
\text { in } \mathrm{RBC} \text { " }\end{array}$ \\
\hline $\begin{array}{l}\text { Group II } \\
\text { (myopathy } \\
\text { only) }\end{array}$ & $3 / 3(9 \%)$ & ND-17 & ND & $0-6$ & ND-17 & ND & ND & $\begin{array}{l}\text { Muscle and hepatic } \\
\text { glycogenesis; CNS } \\
\text { symptoms; low 2,3-DPG. }\end{array}$ \\
\hline $\begin{array}{l}\text { Group III } \\
\text { (hemolysis } \\
\text { only) }\end{array}$ & $3 / 3(9 \%)$ & $9-18$ & $5-15$ & ND-100 & $8-62$ & ND & ND & $\begin{array}{l}\text { Normal ischemic exercise; } \\
\text { unstable PFK with } \\
\text { aberrant kinetics. }\end{array}$ \\
\hline $\begin{array}{l}\text { Group IV } \\
\quad \text { (asymptomatic) }\end{array}$ & $5 / 3(9 \%)$ & $14-18$ & $1-2$ & ND-78 & $28-66$ & $75 \pm 6(2)$ & $88 \pm 4(2)$ & $\begin{array}{l}\text { Unstable } M \text { or } L \text { type } \\
\text { subunits; decreased } L_{4} \text { and } \\
\text { L-containing isozymes; } \\
\text { aberrant kinetics. }\end{array}$ \\
\hline $\begin{array}{l}\text { Group V (fatal } \\
\text { myopathies) }\end{array}$ & $5 / 3(9 \%)$ & ND & ND & $1-6$ & ND-75 & ND & ND & $\begin{array}{l}\text { Muscle glycogenesis; } \\
\text { congenital onset; atypical } \\
\text { symptoms. }\end{array}$ \\
\hline
\end{tabular}

* DiMauro, S., 1985, unpublished results. ${ }^{\ddagger}$ Percent of total unrelated kindreds. ${ }^{8}$ Includes five patients from four unrelated kindreds studied but not yet reported by us. "Studies on the patient reported here.

gen storage disease type VII, accounts for almost two-thirds of all the reported cases. So far, we have had opportunities to study nine patients from eight unrelated families presenting with the classic disease, i.e., a simultaneous presence of muscle and red cell diseases (4, 5, Vora, S., unpublished data). Our studies reveal that except for severity of the myopathic syndrome and age of onset of hyperuricemia, glycogenosis type VII shows highly uniform hematological, metabolic, and biochemical profiles (Table IV) (5). The noteworthy features include a higher prevalence in the Jewish population, myopathy beginning in early childhood, muscle glycogenosis, moderately severe hemolytic process without anemia, low red cell 2,3DPG level and early-onset hyperuricemia with or without clinical gout. As a rule, each patient showed a total lack of catalytically active $\mathbf{M}$ subunits, but immunoreactive $\mathbf{M}$ subunits were present in normal amounts $(5,30)$. In each case, a total lack of the $M$ subunit resulted in the pathognomonic presence of isolated liver-type isozyme in the red cells (Fig. 1 $B$ ). So uniform is this feature that we have been able to make a precise diagnosis of muscle PFK deficiency in several kindreds by investigating their red cells only for the presence of muscle PFK subunits (Vora, S., unpublished data). In each case, the muscle disease was typified by easy fatigability and episodic muscle weakness, cramps, and myoglobinuria after exertion.

In contrast, including the patient reported in this article, only three cases of muscle PFK deficiency presenting with late-onset muscle disease are known $(7,9)$. The patient reported by Hays et al. (7) had suffered from mild exercise intolerance all her life, but without muscle cramps or myoglobinuria. She presented at age 61 with chronic and progressive limb-girdle weakness of five years' duration. Hematologically and biochemically, she resembled the patients with the typical disease, but no studies were undertaken to precisely define the nature of her enzymatic lesion.

The results of the various studies in the present patient and his daughter, those available in the other patient with lateonset myopathy (7) and in three patients with the typical early-onset disease (5) are compared in Tables I and IV and Fig. 1. The propositus shows a well-compensated hemolytic process, as do all other patients with typical or atypical presentation. Also like other patients of both groups, the patient shows almost total lack of muscle PFK, increased muscle glycogen, nd decreased red cell PFK activity and 2,3-DPG concentration. Like the early-onset disease patients, he suffers 
from hyperuricemia and gout which began in his early twenties, but have been well controlled over the years by allopurinol. The patient's daughter shows $\sim 63 \%$ of normal PFK activity and $74 \%$ of normal 2,3-DPG level in her red cells, values intermediate between those of her father and the normal individual. A distinct mutation of the $M$ subunit in our patient was suggested by studies of his red cell PFK isozymic composition. In contrast to the isolated $\mathrm{L}_{4}$ type isozyme present in red cells of patients with typical presentation, the residual red cell PFK of the patient consistently showed the presence of a few hybrid isozymes of $\mathrm{M}+\mathrm{L}$, in addition to the predominant $\mathrm{L}_{4}$ species (Fig. $1 C$ ). His daughter's red cells showed an almost identical isozyme profile except for a greater amount of the hybrid species (Fig. $1 D$ ). The presence of a minor amount of the $M$ subunit in red cells of father and daughter was confirmed by immunological means. The residual red cell PFK from patients with the classic disease is not precipitated by the anti-M monoclonal antibody, indicating a total lack of the catalytically active $M$ subunit. In contrast, $\sim 40 \%$ and $60 \%$ of the red cell PFK from the patient and his daughter are precipitated by the anti-M antibody (Table II). A contamination of the anti-M antibody by anti-L antibody was ruled out by the fact that, as expected, the red cell PFK from two classic disease patients studied concurrently was totally resistant to precipitation. These studies thus rigorously established the existence of the M-type subunits in the patient's red cells.

Mammalian PFKs are known to undergo self-association into high-molecular weight polytetramers that are enzymatically active (14, 31-33). This self-association is governed by protein concentration, $\mathrm{pH}$, and effector and salt concentrations (32). Muscle PFK shows aggregation at concentrations $>0.5 \mathrm{mg} / \mathrm{ml}(31,33)$, whereas the liver $(13,14)$ and red cell (19-22) PFKs show aggregation at much lower concentrations, i.e., $\sim 1 \mu \mathrm{g} / \mathrm{ml}$ and higher. Despite this extreme propensity for self-aggregation, the red cell PFK from the rabbit in native hemolysates (22) and purified red cell enzyme from humans (19) in very dilute enzyme preparations $(0.3 \mu \mathrm{g} / \mathrm{ml})$ exist as tetramers $\left(M_{\mathrm{r}}=\sim 340,000\right)$, as illustrated by active enzyme centrifugation and gel filtration studies. To confirm that the early-eluting isozymes from patient's red cells were not aggregated forms of $\mathrm{L}_{4}$ isozyme or hybrids of $\mathrm{M}+\mathrm{L}$ subunits, we undertook gel filtration studies employing frontal elution chromatography (Fig. 2). Our results show that the enzyme at a concentration of $0.08 \mu \mathrm{g} / \mathrm{ml}$ elutes after ferritin $\left(M_{\mathrm{r}}\right.$ $=440,000)$ and before aldolase $\left(M_{\mathrm{r}}=158,000\right)$, indicating that at this concentration it exists as a tetramer $\left(M_{\mathrm{r}}=330,000\right)$. These results are in accord with those of others $(12-15,19-22)$ and provide additional evidence for the tetrameric nature of PFK during our conditions of chromatography. The fact that early-eluting isozymes are indeed hybrids of $M+L$ subunits was evidenced by the immunoprecipitation studies of the isolated pools of $\mathrm{L}_{4}$ and non- $\mathrm{L}_{4}$ isozymes as well as selected peak fractions thereof (Table III). These results combined with those of chromatographic studies conclusively confirm the presence of heterotetramers containing the $M$ subunit in red cells from the propositus.

These data indicate that the myopathic syndrome in our patient results from a mutation of the $M$ subunit that is distinct from that (or those) causing the typical disease. While the $M$ subunit in our patient appears to be catalytically functional, it may be unstable or synthesized at a greatly reduced rate or it may be incompetent to tetramerize with either the $M$ or $L$ subunit in vivo to the fullest extent to form active enzyme molecules. The absence of a mutant unstable $M$ subunit was suggested by the in vivo stability of residual red cell PFK in the propositus. The PFK activity ratio of his youngest/oldest red cells determined after density-dependent cell separation was essentially normal. However, it is likely that a mutant unstable $M$ subunit is stabilized by tetramerization with the $L$ subunit in the patient.

The late onset of myopathy may be ascribed to the lowlevel presence of muscle PFK activity that may permit some glycolytic flux in vivo. The progression of the weakness in the eighth decade of life may stem from the abnormalities of gene expression and/or regulation known to be associated with normal aging. Recently, we have isolated a complementary DNA (cDNA) for the normal human muscle PFK (34). Currently, efforts are underway to isolate cDNAs for the mutant muscle PFKs from several of our patients, including the one reported here, in order to characterize the defects at the molecular level. Because the late-onset form of PFK deficiency has been documented in at least three patients to date, it is appropriate that it be classified as a new subtype of glycogenosis type VII and be considered in the differential diagnosis of adultonset myopathies of unknown etiologies, especially in Jewish patients.

\section{Acknowledgments}

The authors wish to thank the PFK-deficient patient and his family for their kind cooperation, Steven Turchen for excellent technical assistance, and Nancy McCarthy for assistance in preparing the typescript.

This research was supported by the National Institutes of Health grants AM-33445, NS-11766, AM-25500, and grants from the Muscular Dystrophy Association and March of Dimes (6-383). Dr. Vora is the recipient of a Research Career Development Award (KO4 AM-01260) from the National Institutes of Health.

\section{References}

1. Vora, S., C. Seaman, S. Durham, and S. Piomelli. 1980. Isozymes of human phosphofructokinase: identification and subunit structural characterization of a new system. Proc. Natl. Acad. Sci. USA. 77:62-66.

2. Vora, S. 1981. Isozymes of human phosphofructokinase in blood cells and cultured cell-lines: molecular and genetic evidence for a trigenic system. Blood. 57:724-732.

3. Vora, S., L. A. Wims, S. Durham, and S. L. Morrison. 1981. Production of monoclonal antibodies to the subunits of human phosphofructokinase: new tools for the immunochemical and genetic analyses of isozymes. Blood. 58:823-839.

4. Vora, S. 1982. Isozymes of phosphofructokinase. Isozymes Curr. Top. Biol. Med. Res. 6:119-167.

5. Vora, S., M. Davidson, C. Seaman, A. F. Miranda, N. A. Nobel, K. R. Tanaka, E. P. Frenkel, and S. DiMauro. 1983. Heterogeneity of the molecular lesions in inherited phosphofructokinase deficiency. $J$. Clin. Invest. 72:1995-2006.

6. Vora, S., U. Giger, S. Turchen, and J. W. Harvey. 1985. Characterization of the enzymatic lesion in inherited phosphofructokinase deficiency in the dog: an animal analogue of human glycogen storage disease type VII. Proc. Natl. Acad. Sci. USA. 82:8109-8113.

7. Hays, A. P., M. Hallett, J. Deifs, J. Morris, A. Sotrel, M. J. M. Shevchuk, and S. DiMauro. 1981. Muscle phosphofructokinase defi- 
ciency: abnormal polysaccharide in a case of late-onset myopathy. Neurology. 31:1077-1086.

8. Danon, M. J., S. DiMauro, N. Bresolin, S. Shanske, and S. Vora. 1985. Late-onset muscle phosphofructokinse (PFK) deficiency. Neurology. 35:207. (Abstr.)

9. Beutler, E., C. West, and K. G. Blume. 1976. The removal of leukocytes and platelets from whole blood. J. Lab. Clin. Med. 88:328333.

10. Davidson, M., M. Collins, J. Byrne, and S. Vora. 1983. Alterations in phosphofructokinase isozymes during early human development. Establishment of adult organ-specific patterns. Biochem. J. 214:703-710.

11. Winzor, D. J. 1969. Analytical gel filtration. In Physical Principles and Techniques of Protein Chemistry, Part A. S. J. Leach, editor. Academic Press, New York. 451-495.

12. Pavelich, M. J., and G. G. Hammes. 1973. Aggregation of rabbit muscle phosphofructokinase. Biochemistry. 12:1408-1414.

13. Reinhart, G. D., and H. A. Lardy. 1980. Rat liver phosphofructokinase: use of fluorescence polarization to study aggregation at low protein concentration. Biochemistry. 19:1484-1490.

14. Reinhart, G. D., and H. A. Lardy. 1980. Rat liver phosphofructokinase: kinetic and physiological ramifications of the aggregation behavior. Biochemistry. 19:1491-1495.

15. Hand, S. C., and G. N. Somero. 1982. Urea and methylamine effects on rabbit muscle phosphofructokinase: catalytic stability and aggregation state as a function of $\mathrm{pH}$ and temperature. J. Biol. Chem. 257:734-741.

16. Vora, S., S. Durham, B. de Martinville, D. L. George, and U. Francke. 1982. Assignment of the human gene for muscle-type phosphofructokinase (PFKM) to chromosome 1 (cen $\rightarrow$ q32) using somatic cell hybrids and monoclonal anti-M antibody. Somatic Cell Genet. 8:95-104.

17. Beutler, E. 1984. Red Cell Metabolism: A Manual of Biochemical Methods. 3rd ed. Grune and Stratton, Inc., New York.

18. Vettore, L., M. C. DeMatteis, and P. Zampini. 1980. A new density gradient system for the separation of human red cells. Am. J. Hematol. 8:291-297.

19. Karadsheh, N. S., K. Uyeda, and R. M. Oliver. 1977. Studies on structure of human erythrocyte phosphofructokinase. J. Biol. Chem. 252:3515-3524.

20. Wenzel, K. W., G. Zimmermann, J. Gauer, W. Diezel, S. Liebe, and E. Hofmann. 1972. Evidence for different oligomeric forms of human erythrocyte phosphofructokinase. FEBS (Fed. Eur. Biochem. Soc.) Lett. 19:285-289.

21. Zimmerman, G., K. W. Wenzel, J. Gauer, and E. Hoffman. 1973. Studies on the association behaviour of human-erythrocyte phosphofructokinase. Eur. J. Biochem. 40:501-505.
22. Tarui, S., N. Kono, and K. Uyeda. 1972. Purification and properties of rabbit erythrocyte phosphofructokinase. J. Biol. Chem. 247:1138-1145.

23. Tarui, S., G. Okuno, Y. Ikura, T. Tanaka, M. M. Suda, and M. Nishikawa. 1965. Phosphofructokinase deficiency in skeletal muscle: a new type of glycogenesis. Biochem. Biophys. Res. Commun. 19:517523.

24. Layzer, R. B., L. P. Rowland, and H. M. Ranney. 1967. Muscle phosphofructokinase deficiency. Arch. Neurol. 17:512-523.

25. Chance, B., S. Eleff, W. Bank, J. S. Leigh, Jr., and R. Warnell. 1982. [ $\left.{ }^{32} \mathrm{P}\right] \mathrm{NMR}$ studies of control of mitochondrial function in phosphofructokinase-deficient human skeletal muscle. Proc. Natl. Acad. Sci. USA. 79:7714-7718.

26. Tani, K., H. Fujii, S. Takegawa, S. Miwa, W. Koyama, M. Kanayama, A. Imanaka, F. Imanaka, and A. Kuramoto. 1983. Two cases of phosphofructokinase deficiency associated with congenital hemolytic anemia found in Japan. Am. J. Hematol. 14:165-174.

27. Tani, K., H. Fujii, S. Miwa, F. Imanaka, A. Kuramoto, and H. Ishikawa. 1983. Phosphofructokinase deficiency associated with congenital nonspherocytic hemolytic anemia and mild myopathy: biochemical and morphological studies on the muscle. Tohoku J. Exp. Med. 141:287-293.

28. Shimizu, T., M. Kuwajima, N. Kono, I. Mineo, S. Sumi, T. Yonezawa, K. Noneka, and S. Tarui. 1983. Kinetic properties of mutant enzymes in erythrocyte phosphofructokinase deficiency and erythrocyte pyruvate kinase deficiency. Med. J. Osaka Univ. 33:49-58.

29. Etiemble, J., J. Simeon, H. A. Buc, C. Picat, M. Boulard, and P. Boivin. 1983. A liver-type mutation in a case of pronounced erythrocyte phosphofructokinase deficiency without clinical expression. Biochim. Biophys. Acta. 795:236-242.

30. Davidson, M., A. F. Miranda, A. N. Bender, S. DiMauro, and S. Vora. 1983. Muscle phosphofructokinase deficiency. Biochemical and immunological studies of phosphofructokinase isozymes in muscle culture. J. Clin. Invest. 72:545-550.

31. Aaronson, R. P., and C. Frieden. 1972. Rabbit muscle phosphofructokinase: studies on the polymerization. The behavior of the enzyme at $\mathrm{pH} 8, \mathrm{pH} 6$, and intermediate $\mathrm{pH}$ values. J. Biol. Chem. 247:7502-7509.

32. Lad, P. M., D. E. Hill, and G. G. Hammes. 1973. Influence of allosteric ligands on the activity and aggregation of rabbit muscle phosphofructokinase. Biochemistry. 12:4303-4309.

33. Leonard, K. R., and I. O. Walker. 1972. The self-association of rabbit-muscle phosphofructokinase. Eur. J. Biochem. 26:442-448.

34. Vora, S., F. Hong, and E. Olender. 1985. Isolation of a cDNA for human muscle 6-phosphofructokinase. Biochem. Biophys. Res. Commun. 135:615-621. 